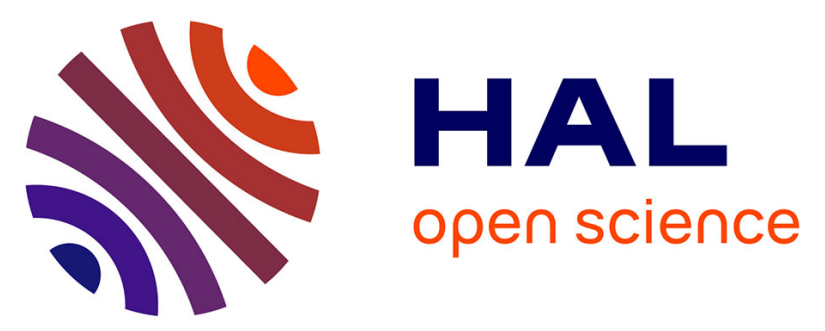

\title{
Colloidal and chemical stabilities of iron oxide nanoparticles in aqueous solutions: the interplay of structural, chemical and environmental drivers
}

Edwige Demangeat, Mathieu Pédrot, Aline Dia, Martine Bouhnik-Le Coz, Fabien Grasset, Khalil Hanna, M. Kamagaté, Francisco Cabello-Hurtado

\section{To cite this version:}

Edwige Demangeat, Mathieu Pédrot, Aline Dia, Martine Bouhnik-Le Coz, Fabien Grasset, et al.. Colloidal and chemical stabilities of iron oxide nanoparticles in aqueous solutions: the interplay of structural, chemical and environmental drivers. Environmental science.Nano, 2018, 5 (4), pp.9921001. 10.1039/C7EN01159H . insu-01737100

\section{HAL Id: insu-01737100 \\ https://hal-insu.archives-ouvertes.fr/insu-01737100}

Submitted on 28 Oct 2020

HAL is a multi-disciplinary open access archive for the deposit and dissemination of scientific research documents, whether they are published or not. The documents may come from teaching and research institutions in France or abroad, or from public or private research centers.
L'archive ouverte pluridisciplinaire HAL, est destinée au dépôt et à la diffusion de documents scientifiques de niveau recherche, publiés ou non, émanant des établissements d'enseignement et de recherche français ou étrangers, des laboratoires publics ou privés. 


\section{Sano}

\section{Accepted Manuscript}

This article can be cited before page numbers have been issued, to do this please use: E. Demangeat, $M$. Pedrot, A. Dia, M. Bouhnik-Le-Coz, F. Grasset, K. Hanna, M. Kamagate and F. Cabello-Hurtado, Environ. Sci.: Nano, 2018, DOI: 10.1039/C7EN01159H.

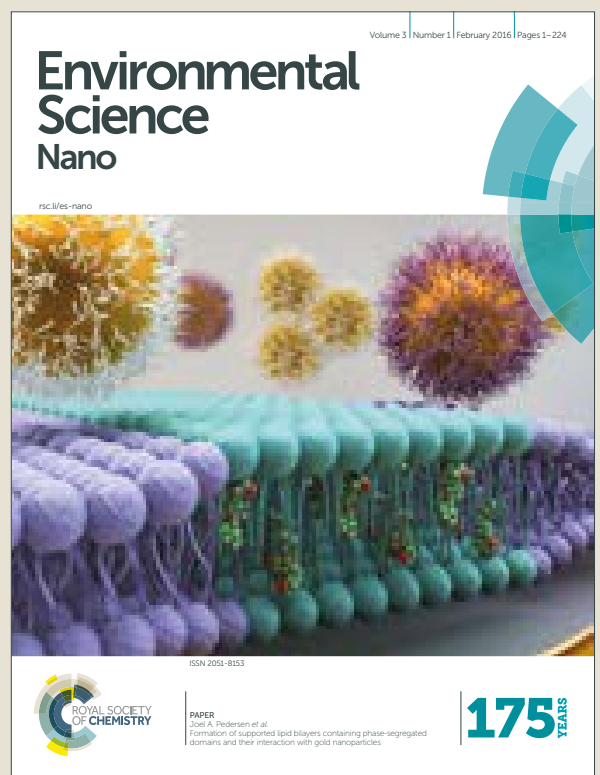

This is an Accepted Manuscript, which has been through the Royal Society of Chemistry peer review process and has been accepted for publication.

Accepted Manuscripts are published online shortly after acceptance, before technical editing, formatting and proof reading. Using this free service, authors can make their results available to the community, in citable form, before we publish the edited article. We will replace this Accepted Manuscript with the edited and formatted Advance Article as soon as it is available.

You can find more information about Accepted Manuscripts in the author guidelines.

Please note that technical editing may introduce minor changes to the text and/or graphics, which may alter content. The journal's standard Terms \& Conditions and the ethical guidelines, outlined in our author and reviewer resource centre, still apply. In no event shall the Royal Society of Chemistry be held responsible for any errors or omissions in this Accepted Manuscript or any consequences arising from the use of any information it contains. 


\section{Environmental significance statement}

Amongst engineered nanoparticles, iron oxide nanoparticles (IONPs) appear particularly relevant toward the environment. Indeed, considering their potential uses in environmental fields (water and soil depollution, agrochemistry, etc.), it becomes critical to determine their behavior and fate in the environment. Their stability and reactivity are dependent upon the environmental parameters, and both intrinsic and surficial properties of IONPs. This work focused on the aggregation behavior of IONPs (especially magnetite, maghemite, hematite), their chemical transformation (oxidation of magnetite) and the impact of a surface coating that mimic natural interactions possibly occurring in the environment. Understanding these interactions and transformations will thus bring key insights regarding the mobility, bioavailability and chemical reactivity of IONPs in prevailing environmental conditions. 


\title{
Environmental Science: Nano
}

Received 29th November 2017, Accepted 00th January 20xx

DOI: $10.1039 / \mathrm{x} 0 \times x \times 00000 \mathrm{x}$ www.rsc.org/

\section{Colloidal and chemical stabilities of iron oxide nanoparticles in aqueous solutions: the interplay of structural, chemical and environmental drivers}

\author{
E. Demangeat, ${ }^{a}$ M. Pédrot, ${ }^{a}$ A. Dia, ${ }^{a}$ M. Bouhnik-le-Coz, ${ }^{a}$ F. Grasset,,${ }^{b}$ K. Hanna, ${ }^{c}$ M. Kamagate ${ }^{c}$ and F. \\ Cabello-Hurtado ${ }^{d}$
}

\begin{abstract}
Nanoparticle (NP) stability in aqueous environments is dependent upon many parameters including environmental conditions, NP concentrations as well as NP intrinsic characteristics. In this study, the effects of $\mathrm{pH}$ and surface modifications on the colloidal and chemical stabilities of nanosized magnetite $\left(\mathrm{Fe}_{3} \mathrm{O}_{4}\right)$, maghemite $\left(\gamma-\mathrm{Fe}_{2} \mathrm{O}_{3}\right)$ and hematite $\left(\alpha-\mathrm{Fe}_{2} \mathrm{O}_{3}\right)$ are investigated. Because changes in surface charge affect the size distribution of NP, pH plays a key role in driving the colloidal stability. More NP aggregation is observed at $\mathrm{pH}$ values close to the $\mathrm{pH}$ of zero point of charge (pHzpc). Coating of magnetite with humic acid (HA) and phosphatidylcholine (PC) affects the electrostatic interactions and then the colloidal behavior of NP. The rapid transformation of magnetite into maghemite through air oxidation results in significant modification of both surface charge and specific surface area of NP. Because the maghemite almost exclusively formed $\mu \mathrm{m}$-scale aggregates, the colloidal stability of magnetite is expected to be hindered in oxic environments. For hematite, the particle size distribution data emphasize the influence of both $\mathrm{pH}$ and intrinsic surface properties in colloidal stability. These findings may have strong implications for an accurate prediction of the transformation and mobility of Fenanoparticles under environmentally relevant conditions and thus their fate in nature.
\end{abstract}

\section{Introduction}

${ }_{27}$ Engineered iron oxide NP will become new tools for the treatmen ${ }_{2}$ Understanding the prevailing processes controlling chemical 28 of contaminated waters and soils ${ }^{14,15}$. As compared to conventional 3 exchanges at soil/water interfaces is an environmental priority with 29 macroscale materials, nanomaterials exhibit a high surface-to4 regards to their impacts on both ecosystems and soil services, as 30 volume ratio and high reactivity. Thus, their colloidal size may give 5 well as water resources. Iron ( $\mathrm{Fe}$ ) oxides are ubiquitous minerals 31 them high mobility in porous media and their properties allow them 6 constituent of soils, sediments, aquifers and geological materials ${ }^{1,2}$. 32 to be particularly suitable for the treatment of contaminated soils 7Their origin is also anthropogenic as they are increasingly used in 33 or aquifers. Iron oxide NP are involved in (i) the dechlorination of 8 various fields such as for industrial, medical and environmental 34 organic solvents $\left(\mathrm{CCl}_{4}, \mathrm{C}_{2} \mathrm{Cl}_{4}\right)$, (ii) the detoxification of pesticides 9purposes $^{3-6}$. Iron oxides nanoparticles (NP) respective stability, 35 (such as Lindane, DDT), (iii) the transformation of fertilizers $\left(\mathrm{NO}_{3}{ }^{-}\right)$, 10specific surface area, porosity, dissolution rate as well as 36 and (iv) the immobilization of metals and metalloids (As, $\mathrm{Pb}, \mathrm{Cr}$, 11 transformation kinetics are controlled by their mineral structure $37 \mathrm{etc}$. $)^{16-18}$. If remediation projects using iron oxide NP are currently 12 and determine their fate and behaviour in the environment ${ }^{7}$. 38 focused on local-scale pollution, a scale change is initiated to act 13 Amongst them, iron oxide nanoparticles, which also occur as 39 against diffuse pollution. Moreover, their use in nano14 ubiquitous phases in both soils and waters, play a critical role in the 40 agrochemistry could be developed in the years ahead and would 15 chemical dynamics resulting from environmental condition changes 41 represent an intentional diffuse source of iron oxide NP within the 16 since nano minerals are highly reactive ${ }^{8,9}$. In the natural conditions, 42 environment ${ }^{19}$. A widespread use of iron oxide NP for in situ 17 only a small fraction of engineered iron oxide NP persists in its 43 remediation or in agriculture also raises the question of their 18 original form ${ }^{10}$. Biotransformation, oxidation/reduction, dissolution, 44 environmental compatibility.

19 precipitation, sorption and photochemical transformation may 45 Amongst engineered iron oxide NP of environmental concern, 20 occur amongst other biogeochemical driven processes ${ }^{11,12}$. In turn, 46 magnetite $\left(\mathrm{Fe}_{3} \mathrm{O}_{4}\right)$, maghemite $\left(\gamma-\mathrm{Fe}_{2} \mathrm{O}_{3}\right)$ and hematite $\left(\alpha-\mathrm{Fe}_{2} \mathrm{O}_{3}\right)$ are 21 this transformation can affect the aggregation, mobility, 2?

2: Univ. Rennes, CNRS, Géosciences Rennes - UMR 6118 -F- 35000 Rennes, France

2. Univ. Rennes, CNRS-Saint-Gobain-NIMS-UMI LINK 362-J-305-044, Tuskuba, Japan

2،. Univ. Rennes, ENSCR-CNRS, ISCR (Institut des Sciences Chimiques de Rennes) - UMR 6226 F-35000 Rennes, France

d. Univ. Rennes, CNRS, Ecobio - UMR 6553 - F-35000 Rennes, France 47 popular engineered iron oxide NP because of their biocompatibility 48 and safety towards living organisms under certain conditions ${ }^{20-22}$. In 49 particular, magnetite has shown an outstanding applicability in 50 many research areas (e.g., semiconductor, magnetic resonance 51 imaging, pigment, biomedicine, drug delivery, heterogeneous 

53 magnetic properties and easy manipulation for control of 106 for iron oxide NP interactions ${ }^{46}$ occurring at mineral surfaces and in 54 morphologies, particle size, and $\mathrm{Fe}^{\prime \prime} / \mathrm{Fe}^{\mathrm{III}}$ stoichiometry ${ }^{26,}{ }^{27}$. 107 water. In addition to particle interactions, NP are prone to various 55 However, determination of magnetite compositions which is highly 108 chemical and physical modifications which foster the complexity of 56 sensitive to the preparation conditions is not a trivial task, 109 the reactions and likely affect both NP stability and reactivity. 57 particularly for nanoscale particles with a higher surface-to-volume 110 Electrostatic, steric or combined electrosteric forces can result from 58 ratio. Magnetite compositions range, without modification of the 111 these interactions and promote repulsive forces whereas Van der 59 crystal structure, from that of stoichiometric $\mathrm{Fe}_{3} \mathrm{O}_{4}$, with $8 \mathrm{Fe}^{3+}$ ions 112 Waals and magnetic dipolar interactions foster attraction between 6oin tetrahedral and $8 \mathrm{Fe}^{2+}+8 \mathrm{Fe}^{3+}$ ions in octahedral sites, to that of 113 particles that likely aggregate. The intrinsic physicochemical 61 maghemite $\mathrm{\gamma}-\mathrm{Fe}_{2}{ }_{2} \mathrm{O}_{3}$ (considered as an extreme example of a non-114 properties of iron oxide NP (size, shape, surface area, chemistry, 62 stoichiometric magnetite) with only $\mathrm{Fe}^{3+}$ ions in both tetrahedral 115 superparamagnetism, etc.), their ensuing high reactivity, together 63 and octahedral sites. As compared to these iron oxides, hematite 116 with the surrounding solution composition (dissolved species, $\mathrm{pH}$, 64 has only one type of cation, $\mathrm{Fe}^{3+}$ in its structure ${ }^{28,29}$. 117 ionic strength, nanoparticle concentration), are the main drivers of 65 In aqueous solution, iron oxides (IO) are amphoteric solids that 118 iron oxide NP chemical and colloidal stability in aqueous media ${ }^{47,48}$. 66 acquire a surface charge in the protonation and deprotonation 119 Considering the geochemical, biological and technological 67 reactions of $\mathrm{Fe}-\mathrm{OH}$ surface sites. The ensuing electrostatic, steric or 120 significance of iron oxide $\mathrm{NP}^{49}$, understanding the mechanisms of 68 combined stabilization layers that develop at the surface of the 121 their stability may turn out to be relevant to unravel the fate and 69 particles are significant in driving iron oxide NP colloidal stability ${ }^{30} .122$ behaviour of iron oxide NP in the environment as well as their 70 The interfacial equilibrium at the surface of iron oxide NP is thus 123 impacts on living organisms. Therefore, the aim of this work is to 71 affected by the adsorption and desorption of the various 124 investigate the dual colloidal and chemical stability of magnetite NP 72 constituents of the soil and soil solution in addition to the solution 125 in order to (i) understand the effects of their intrinsic properties $73 \mathrm{pH}^{31,32}$. The surface charge of iron oxide NP is also dependent upon 126 (size, morphology, surface chemistry) and those of the 74their own structural organization such as isomorphic substitutions, 127 environmental drivers (especially the effect of $\mathrm{pH}$ ) on their 75 which give iron oxide NP permanent charges.

128 aggregation state, (ii) assess the oxidation kinetics of magnetite, (iii) 76 As part of the Natural Organic Matter (NOM) occurring within 129 investigate the link between colloidal and chemical stability of NP, 77 soils and waters, macromolecular polyfunctional humic acid (HA), 130 as well as (iv) identify the resulting environmental impacts. 78 which displays a particular affinity for metal ions and their various 131 Hematite has also been studied to better understand the impact of 79 acidic functional groups (carboxylic, phenolic, carbonyl), favours the 132 intrinsic structural properties on iron oxide NP colloidal stability as 80 formation of surface complexes on the Fe- $\mathrm{OH}$ sites of iron oxides 133 the structure of hematite differs from both magnetite and 81 via chemisorption ${ }^{.33}$. As a consequence, interactions between iron 134 maghemite. Indeed hematite NP size and morphology as well as 82 oxide NP and HA should be further investigated. Several studies 135 internal crystal structure, generally confer a higher stability and 83 have shown that, in aqueous solution, the HA coating on iron oxide 136 crystallinity to hematite. Last, the method we chose to study the ${ }_{84} \mathrm{NP}$ likely imparts a negative charge to the nanoparticle surfaces, 137 iron oxide NP aggregation state allowed us to study their size 85 increasing their surface potential and the ensuing propensity to 138 distribution over a wide range of sizes (that spread from one tenth 86 stabilize iron oxide NP against aggregation ${ }^{34-36}$. Nevertheless, Hadju 139 of a nm to $\mu \mathrm{m}$-scale aggregates) which allowed us to determine NP $87 \mathrm{et} \mathrm{al.}^{37}$ demonstrated that coating magnetite with HA could either 140 behavior in a context comparable to those observed in natural 88 foster or hinder $\mathrm{Fe}_{3} \mathrm{O}_{4}$-NP colloidal stability depending on the 141 waters.

89 amount of $\mathrm{HA}$ present at the mineral surfaces. Other natural 90 constituents such as amphiphilic phospholipids (integral major 91 component of cell membranes) likely affect iron oxide NP stability. ${ }^{142}$ Experimental ${ }_{92}$ Using phospholipids as a coating on pyrite surfaces, Hao et al. ${ }^{38}{ }_{143}$ Iron oxide nanoparticles and coated magnetite NP ${ }_{93}$ demonstrated that surface-bound lipids inhibit the iron core from ${ }^{144}$ Synthesis of bare iron oxide NP. Magnetite $\left(\mathrm{Fe}_{3} \mathrm{O}_{4}\right)$ was $940 x i d i z i n g$, even in the presence of bacteria, by forming a 145 prepared by the co-precipitation of iron salts according to the

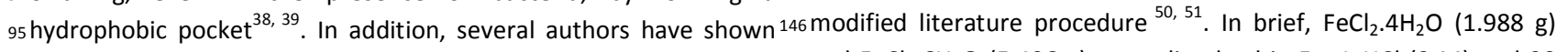
96 that a phospholipid coating likely decreases nanoparticle size 147 and $\mathrm{FeCl}_{3} \cdot 6 \mathrm{H}_{2} \mathrm{O}(5.406 \mathrm{~g}$ ) were dissolved in $5 \mathrm{~mL} \mathrm{HCl}(2 \mathrm{M})$ and 20 97 dispersion and favours narrow-sized nanoparticles ${ }^{40,}{ }^{41} .148 \mathrm{~mL} \mathrm{H}_{2} \mathrm{O}$, respectively, and then mixed with magnetic stirring to 98 Furthermore, the instability of magnetite in air causes NP to 149 obtain an iron solution with a molar ratio of $\mathrm{Fe}(\mathrm{II}) / \mathrm{Fe}(\mathrm{III})=0.5$. 99 undergo a partial oxidation to maghemite $\left(\gamma-\mathrm{Fe}_{2} \mathrm{O}_{3}\right)$, ending up with ${ }^{150}$ Magnetite NP were then precipitated by the dropwise addition of 100 a core-shell structure in which the thickness of the oxidized layer is 151 the iron salt solution into a $0.7 \mathrm{M} \mathrm{NaOH}-\mathrm{NaNO}_{3}$ base solution $(250$ 101 a function of the particle size $\mathrm{e}^{42,43}$. This phase transformation $152 \mathrm{~mL}$ ). The black precipitate was left to settle in anaerobic conditions 102 directly affects the surficial properties and internal characteristics ${ }^{153}$ for a few hours to get rid of the supernatant. Three washings were 103 of NP, which are deeply involved in driving iron oxide chemical 154 then conducted in anaerobic conditions with deoxygenated 104 stability and reactivity ${ }^{44,45}$. 155 deionized water and $510^{-3} \mathrm{M} \mathrm{NaCl}$ solution. 
156 Maghemite $\left(\gamma-\mathrm{Fe}_{2} \mathrm{O}_{3}\right)$ was synthesized following the method of 209 re-solubilized in $0.37 \mathrm{M} \mathrm{HNO}_{3}$ after complete evaporation before 157 Anna et al. $^{52}$, through the oxidation of the previously synthesized 210 measurement. Major- and trace-element concentrations were 158 magnetite by adding $5 \mathrm{wt} \% \mathrm{NaOCl}$ aqueous solution $(16 \mathrm{~mL}$ ) and 211 determined by ICP-MS (Agilent 7700x), using rhenium and rhodium 159 sonicating for 2 hours. The solid product was magnetically 212 as the internal standard. The international geostandard SLRS-5 was 160 separated and washed with water. 213 used to check the validity and reproducibility of the results ${ }^{53}$.

161 Hematite $\left(\alpha-\mathrm{Fe}_{2} \mathrm{O}_{3}\right)$ was synthesized by the forced hydrolysis of acid 214 ${ }_{162} \mathrm{Fe}(\mathrm{III})$ salt solutions at $98^{\circ} \mathrm{C}$ from $0.02 \mathrm{M} \mathrm{Fe}\left(\mathrm{NO}_{3}\right)_{3}$ following the ${ }_{215}$ Characterization 163 protocol described in Schwertmann \& Cornell (2003) ${ }^{1}$. $216 \quad$ Size, morphology and surface properties. The morphology and 164 Coatings with humic acid and phosphatidylcholines. $\mathrm{Fe}_{3} \mathrm{O}_{4}-\mathrm{NP} 217$ individual particle size of $\mathrm{Fe}_{3} \mathrm{O}_{4}, \mathrm{HA}-\mathrm{Fe}_{3} \mathrm{O}_{4}, \mathrm{PC}-\mathrm{Fe}_{3} \mathrm{O}_{4}, \gamma-\mathrm{Fe}_{2} \mathrm{O}_{3}$ and $\alpha-$ 165 were coated with HA (Elliott Soil Humic Acid Standard IV) and PC $\left(1,218 \mathrm{Fe}_{2} \mathrm{O}_{3}\right.$ were determined using High Resolution Transmission 1662-bis (10, 12-tricosadiynoyl)-sn-glycero-3-phosphocholine - CAS219 Electron Microscopy (HR-TEM) with a JEOL2100F (voltage 200 kV). 167 Registry Number: 76078-28-9) to model a natural surface 220 Specimens were prepared by drop-casting diluted Fe-NP 168 modification. The coating was carried out by physical interactions 221 suspensions on 300 mesh Au-grids supported with carbon film.

169 between the dissolved organic species (HA and PC) and a 222 The specific surface area of the iron oxides was determined by 170 concentrated fraction of the $\mathrm{Fe}_{3} \mathrm{O}_{4}$-solution. Humic acid $(0.2 \mathrm{~g})$ was 223 multipoint $\mathrm{N}_{2}-\mathrm{BET}$ (Brunauer Emmett Teller) analysis using a 171 dissolved in $10 \mathrm{~mL} \mathrm{NaOH}(1 \mathrm{M})$ and the obtained $\mathrm{HA}$-solution was 224 Coulter (SA 3100) surface area analyzer.

172 completed to $56 \mathrm{~mL}$ with deionized water. A similar PC-solution was 225 The $\mathrm{pH}$ of zero point of charge was determined by potentiometric 173 obtained by dissolution in deionized water and ultrasonication. 226 titrations, which were conducted with 1 and $2 \mathrm{~g} \mathrm{~L}^{-1}$ of solid at three ${ }_{174}$ Fourty-four $\mathrm{mL}$ of a $6.0 \mathrm{~g} \mathrm{~L}^{-1} \mathrm{Fe}_{3} \mathrm{O}_{4}-\mathrm{NP}$ solution was then added to 227 ionic strengths $\left(10^{-2}, 5.10^{-2}\right.$, and $10^{-1} \mathrm{M}$ of $\left.\mathrm{NaCl}\right)$. The suspension 175 each organic stock solution and each $100 \mathrm{~mL}$ of solution was shaken 228 was purged with nitrogen gas to remove $\mathrm{CO}_{2}$ in a double-walled 176 for 48 hours. At the end of the interaction, five washings were 229 Pyrex cell, which was kept at constant temperature by circulating 177 performed to remove the uncoated materials present in the 230 water from thermostat. Titrations were conducted from 4 to 10 by 178 supernatant after centrifugation. 231 addition of titrant solutions $(\mathrm{HCl}$ or $\mathrm{NaOH})$.

179 Nanoparticle mass concentration measurement. The 232 Synthesized NP were characterized using X-ray powder diffraction 180 concentration of the iron oxide NP solution was inferred from the 233 (XRD). XRD data were collected with a Johanson monochromator ${ }_{181}$ ICP-MS measurements of iron on triplicate samples for the iron $234 \mathrm{using} \mathrm{CuK}_{\alpha}$ radiation $(\lambda=1.5406 \mathrm{~A})$. The $\mathrm{X}$-ray diffractograms were $1820 x i d e$ NP solutions and then recalculated regarding the total 235 found to be identical with the expected oxides.

183 theoretical iron content of the minerals. Each NP sample was 236 Laser particle size analyses allowed the characterization of the size 184 digested with sub-boiled nitric acid $\left(14.6 \mathrm{M} \mathrm{HNO}_{3}\right)$ at $85^{\circ} \mathrm{C}$, and then 237 distribution of magnetite, maghemite, hematite and $\mathrm{HA}$ - and PC185238 $1 8 6 \longdiv { 2 3 9 } 2$

187

188

189

190

191

192

193

194

195

196

197

198

199

200

201

202

203

204

205

206

207

208
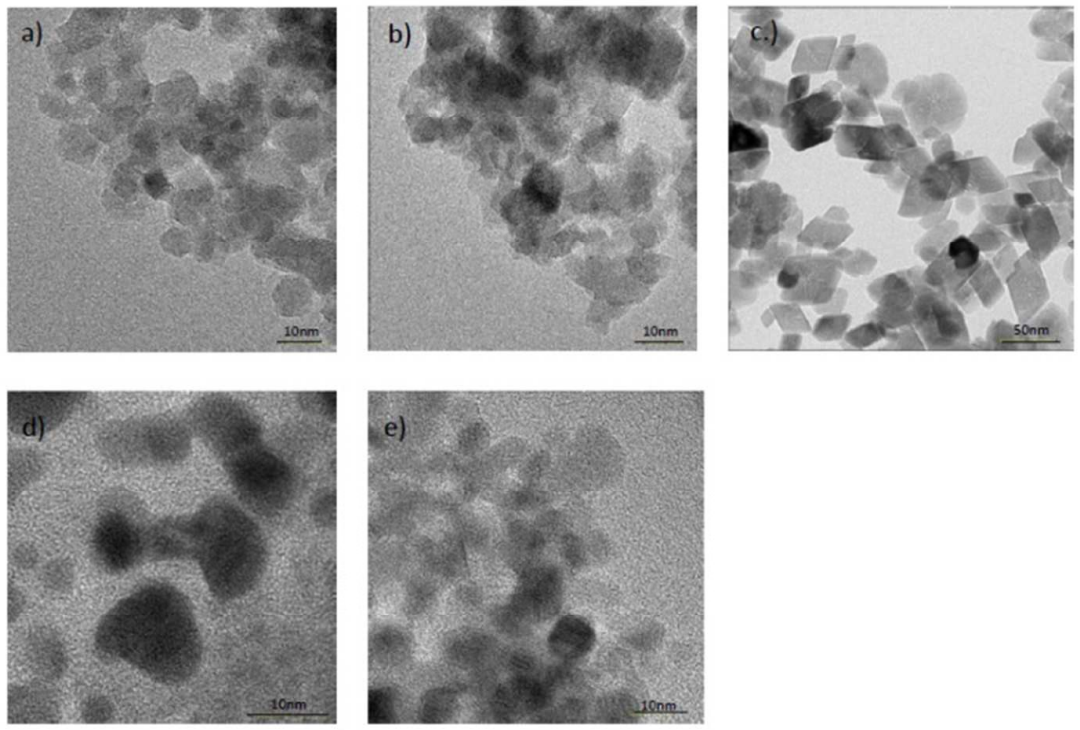

258

250 


\begin{tabular}{l|c|c|c|c|}
\cline { 2 - 5 } 263 & NP & TEM $(\mathbf{n m})$ & BET $\left(\mathbf{m}^{\mathbf{2}} \mathbf{g}^{-1}\right)$ & pHzpc \\
\cline { 2 - 5 } 265 & Magnetite & $7 \pm 2$ & 115 & 5.8 \\
\cline { 2 - 5 } 266 & Maghemite & $6 \pm 2$ & 131 & $7-8.4$ \\
\cline { 2 - 5 } 268
\end{tabular}

260 27 obtained from TEM, BET analyses and potentiometric titration.
27 Table 1: Physicochemical properties of a) $\mathrm{Fe}_{3} \mathrm{O}_{4}$, b) $\gamma-\mathrm{Fe}_{2} \mathrm{O}_{3}$ and c) $\alpha-\mathrm{Fe}_{2} \mathrm{O}_{3}$

317 in Cheng et al. ${ }^{56}$. [ $\left.\mathrm{Fe}(\mathrm{II})\right]$ tot is the total concentration of $\mathrm{Fe}(\mathrm{II})$ in the 318 suspension (solid + solution) and $[\mathrm{Fe}(\mathrm{II})] \mathrm{aq}$ is the dissolved 319 concentration of $\mathrm{Fe}(\mathrm{II})$, measured after filtration $(0.2 \mu \mathrm{m}$, 320 Whatman) of the magnetite suspension. 321

\section{${ }_{322}$ Results and discussion}

\section{Iron oxide NP physicochemical properties.}

${ }_{4}$ HR-TEM analyses provided images to assess the individual sizes and 325 shapes of the nanoparticles (Fig. 1). Magnetite and maghemite 273 coated magnetite to study the colloidal stability and, conversely, $3260 x i d e s$ both displayed rounded shapes and similar sizes with 274 their aggregation behaviour. Assuming measurements on spherical 327 average diameters of $7 \pm 2 \mathrm{~nm}$ and $6 \pm 2 \mathrm{~nm}$ (Table 1), suggesting 275 particles, the technique provided sizes amongst the 100 size classes 328 that the oxidation of magnetite to maghemite did not impact the 276 detected, which spread from $0.04 \mu \mathrm{m}$ to $2500 \mu \mathrm{m}$. Analyses were 329 particle size. Accordingly, BET surface area for maghemite $\left(131 \mathrm{~m}^{2} \mathrm{~g}\right.$ 277 performed by the laser diffraction technique on a Cilas $1180^{330}{ }^{1}$ ) is relatively close to that of magnetite $\left(115 \mathrm{~m}^{2} \mathrm{~g}^{-1}\right)($ Table 1$)$. 278 analyzer. Measurements were taken on each bare iron oxide $\left(\mathrm{Fe}_{3} \mathrm{O}_{4}, 331 \mathrm{Hematite}\right.$ displayed different morphologies with rhombohedral $279 \mathrm{\gamma}-\mathrm{Fe}_{2} \mathrm{O}_{3}$ and $\alpha-\mathrm{Fe}_{2} \mathrm{O}_{3}$ ) and coated magnetite $\left(\mathrm{HA}-\mathrm{Fe}_{3} \mathrm{O}_{4}\right.$ and $\mathrm{PC}-332$ shapes measuring $28 \mathrm{~nm}$-wide and $39 \mathrm{~nm}$-long on average, with a $\left.280 \mathrm{Fe}_{3} \mathrm{O}_{4}\right)$ at five different $\mathrm{pH}$ values $(\mathrm{pH}=3,4,5,6,7.5)$. Particle size 333 surface area of $49 \mathrm{~m}^{2} \mathrm{~g}^{-1}$ (Table 1). No significant changes were 281 measurements were performed by adjusting obscuration values 334 reported for neither HA- nor PC-coated magnetite from TEM 282 allowing for an optimal analysis. Then, the $\mathrm{pH}$ was equilibrated with 335 images, suggesting that the coating process did not modify the

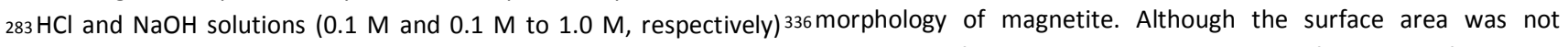
284 until the target $\mathrm{pH}$ was reached. 337 determined for coated materials, no significant modification is 285 ATR-FTIR. Attenuated total reflectance-Fourier transform 338 expected, according to previous findings ${ }^{57}$. 286 infrared (ATR-FTIR) spectra were recorded in the $780-1800 \mathrm{~cm}^{-1} 339$

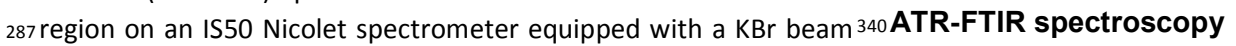

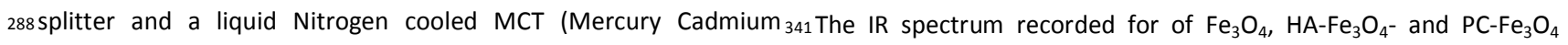
289Telluride) detector. A nine-reflection diamond ATR accessory ${ }_{342}$ showed successful coating of $\mathrm{HA}$ and PC on magnetite surfaces (Fig. 290 (Durasampl/R TM, SensIR Technologies) was used for acquiring ${ }_{343} 2$ ). In the spectra of $\mathrm{HA}-\mathrm{Fe}_{3} \mathrm{O}_{4}$, the presence of an acid carboxylic 291 spectra of wet samples. The resolution of the single beam spectra 344 group was proven by the vibrational bands at $1410 \mathrm{~cm}^{-1}$ and 1614

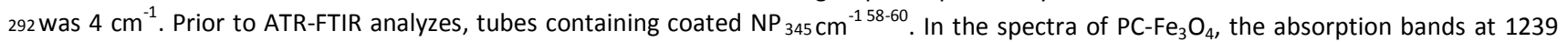
293 were centrifuged at $4110 \mathrm{RCF}$ for $30 \mathrm{~min}$. Wet mineral pastes were $346 \mathrm{~cm}^{-1}, 1088 \mathrm{~cm}^{-1}$ and $970 \mathrm{~cm}^{-1}$ were assigned to the presence of the 294 directly and uniformly applied to the diamond ATR crystal then ${ }_{347} \mathrm{PO}_{4}{ }^{3-}$ group, suggesting that $\mathrm{PC}$ was coated on the magnetite 295 covered with a lid of a flow-through cell to prevent the evaporation ${ }_{348}$ surface $^{61,62}$.

296 of water. ATR-FTIR spectra were then recorded immediately. $\quad 349$ 297 To monitor potential dissolution of NP, aliquots were collected at ${ }_{350}$ Oxidation kinetics 298 each $\mathrm{pH}$ value, centrifuged and the supernatants were filtered using $2995 \mathrm{KDa}$ ultrafiltration cells (from Sartorius) in order to stop NP on the ${ }^{351}$ The variation of total Fe(II)/Fe(III) ratio versus time for magnetite 300 filter. ICP-MS was then performed to measure total iron 352 suspension exposed to air is characterized by a two-steps' behavior. 301 concentration. ${ }_{353}$ Over the four first days (0-96 h), a sharp decrease in total

\section{Oxidation kinetics. A NP suspension $\left(2.5 \mathrm{~g} \mathrm{~L}^{-1}\right)$, prepared in} 303 anoxic conditions, was placed outside the glove box under air ${ }^{35}$ 304 ambient environment to monitor the oxidation. The total $305 \mathrm{Fe}(\mathrm{II}) / \mathrm{Fe}$ (III) ratio in suspension was then analyzed versus time over 35 ! 306 nine days. For each sampling, two aliquots were placed in an 307 anaerobic chamber: the first aliquot contained bulk solution and 35 308 the second was filtered $(0.2 \mu \mathrm{m}$, Whatman). NP suspension was 309 dissolved during $12 \mathrm{~h}$ using $0.6 \mathrm{~N} \mathrm{HCl}$ while filtered NP were directly 35 . 310 dissolved. Dissolved $\mathrm{Fe}(\mathrm{II})$ and $\mathrm{Fe}(\mathrm{III})$ concentrations were then 311 determined using the phenanthroline $\operatorname{method}^{54,55}$ and the bulk ${ }_{35}$ $312 \mathrm{Fe}$ (II) content turned out to be very close to that determined by 313 acid digestion on the filtered solid. The amount of magnetite 314 bound-Fe(II) $([\mathrm{Fe}(\mathrm{II})]$ bound $=[\mathrm{Fe}(\mathrm{II})]$ tot $-[\mathrm{Fe}(\mathrm{II})] \mathrm{aq})$ was used to 315 calculate the effective $\mathrm{Fe}(\mathrm{II}) / \mathrm{Fe}(\mathrm{III})$ ratio (denoted as (Fe(II)/Fe(III)) 316 bound) in magnetite which was shown to vary with $\mathrm{pH}$, as reported

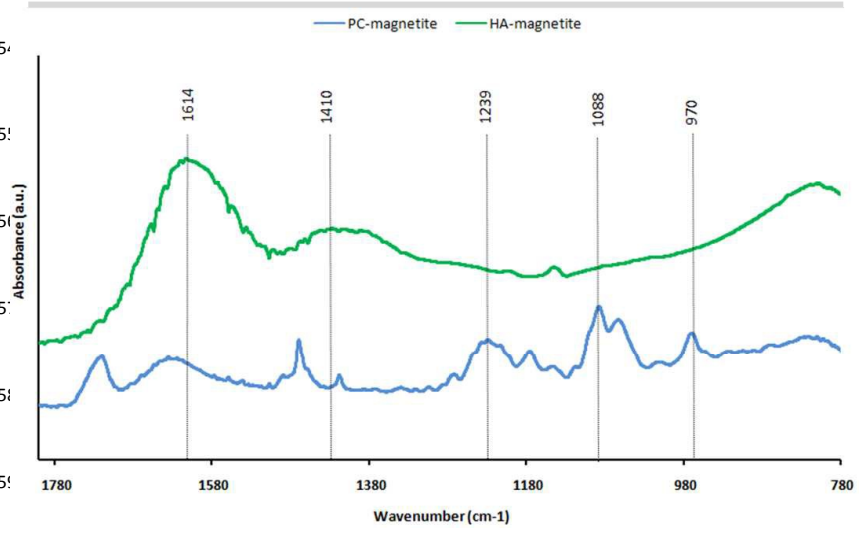

Fig 2: ATR-FTIR spectra of HA-magnetite and PC-magnetite in the range 780$1800 \mathrm{~cm}^{-1}$ obtained from $0.5 \mathrm{~g} \mathrm{~L}^{-1} \mathrm{NP}$ suspensions at $\mathrm{pH}=6$. 


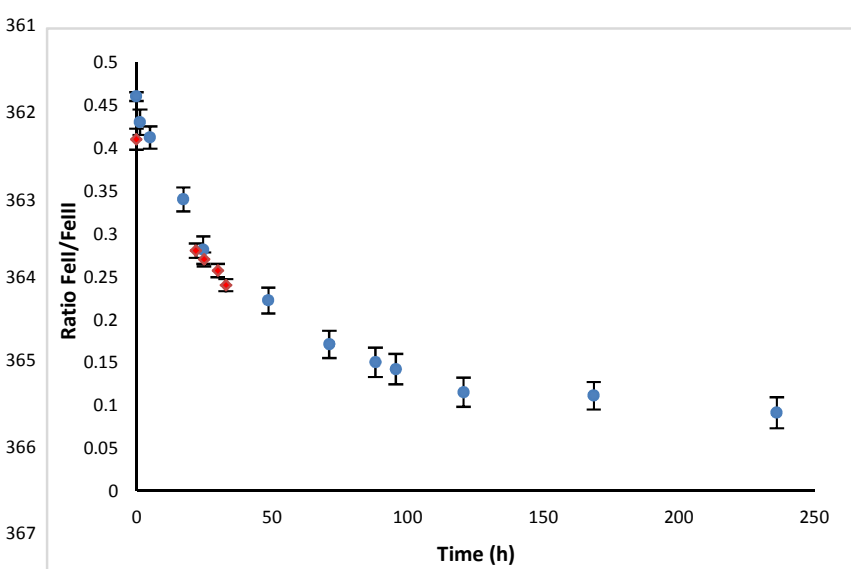

3 Fig 3: Evolution of the total $\mathrm{Fe}(\mathrm{II}) / \mathrm{Fe}$ (III) ratio (blue circles) and bound $\mathrm{Fe}(\mathrm{II}) / \mathrm{Fe}$ (III) ratio (red diamond) as a function of time. The reaction was performed with $2.5 \mathrm{~g} \mathrm{~L}^{-1}$ magnetite NP at $\mathrm{pH}=7.5$ in oxic conditions.

$370 \mathrm{Fe}(\mathrm{II}) / \mathrm{Fe}$ (III) ratio was observed (from 0.46 to 0.09 ). During this first 371 stage, the bound $\mathrm{Fe}(\mathrm{II}) / \mathrm{Fe}(\mathrm{III})$ ratio was also decreased for 372 magnetite as represented by red symbols in Figure 3 . Then, the 373 total $\mathrm{Fe}(\mathrm{II}) / \mathrm{Fe}$ (III) ratio slightly decreased beyond 5 days to reach 3740.09 at the end of the experiment $(236 \mathrm{~h}$ ). As expected from the 375 magnetite solubility at $\mathrm{pH}=7.5^{1}$, very little difference was observed 376 between the total and bound $\mathrm{Fe}(\mathrm{II}) / \mathrm{Fe}(\mathrm{III})$ ratios. 377

\section{Aggregation state}

379 To assess the effect of $\mathrm{pH}$ and the effects of coating, lase 380 diffraction analyses were performed on each iron oxide $\left(\mathrm{Fe}_{3} \mathrm{O}_{4}, \mathrm{HA}\right.$ ${ }_{381} \mathrm{Fe}_{3} \mathrm{O}_{4}, \mathrm{PC}-\mathrm{Fe}_{3} \mathrm{O}_{4}, \gamma-\mathrm{Fe}_{2} \mathrm{O}_{3}$ and $\alpha-\mathrm{Fe}_{2} \mathrm{O}_{3}$ ) at five different $\mathrm{pH}$ values. 382 For all experiments, the aggregation state was associated with the 383 size distribution of the NP, which was described by considering the 384 evolution of the sizes (based on number analyses) with the $\mathrm{pH}$, 385 occurrence rate and the polydispersity of the sizes (PDI, size range, 386 mode and mean) of each iron oxide NP.

387

388

389

390

391

392

393

394

395

396

397

398

399

400

401

404 Effects of $\mathrm{pH}$. The impact of $\mathrm{pH}$ on particle size distribution 405 provides valuable information that could be used to distinguish the 406 colloidal stability from the aggregation state of the various NP 407 (Table 2). The different $\mathrm{pH}$-dependent configurations highlighted 408the role of $\mathrm{pHzpc}$ in controlling NP aggregation through 409 electrostatic interactions (Fig. 4). The effect of $\mathrm{pH}$ was studied by 410 considering the evolution of the size distributions into four size 411 classes (Fig. 4). The fractions were defined with regards to the most 412 common sizes (representability) and depending on the way they 413 vary with $\mathrm{pH}$. However, it should be noted that fractions are not 414 fully comparable to one another, as they were not spread out 415 equally (i.e. fraction $>0.4 \mu \mathrm{m}$ ( $\mu \mathrm{m}$-scaled size class) as compared to 416 40-100 nm fraction (nm-scaled sizes)). The full-size distribution 417 diagrams obtained from laser particle analyses as well as the 418 precise occurrence rates (detectors) are provided in the Electronic 419 Supporting Information (ESI).

420 It is worth noting that the total dissolved iron content was only 421 detected in the magnetite suspension at $\mathrm{pH}=3$ and $\mathrm{pH}=4$ (90 and $42223 \mu \mathrm{mol} \mathrm{L}^{-1}$ respectively). These values correspond to $1.4 \%$ and 0.4 $423 \%$, respectively, of the total iron amount in NP suspension. For HA424 and PC-magnetite samples, no dissolved iron was detected ${ }_{425}$ regardless of the investigated $\mathrm{pH}$.

427 Magnetite. The NP size distribution displayed two configurations: at $428 \mathrm{pH}=5,4$ and 3, magnetite NP showed colloidal stability as 429 compared to their size distribution at $\mathrm{pH}=6$ and 7.5. Magnetite size 430 distribution at acidic $\mathrm{pH}$ was characterized by a high proportion of 431 small NP $(\leq 0.04 \mu \mathrm{m})$, and the occurrence of few dispersed $\mu \mathrm{m}$ 432 scaled aggregates (with sizes ranging between $1.6 \mu \mathrm{m}$ and $32 \mu \mathrm{m}$ ).

${ }_{433}$ Such distribution allowed a large amount of NP not to sediment, as 434 defined by Buffle et al. ${ }^{63}$. When the $\mathrm{pH}$ increased to 6 and 7.5, the 435 number of coarser $100-400 \mathrm{~nm}$ and 40-100 nm-sized aggregates 436 increased as the proportion of small aggregates decreased. This is 437 consistent with the measured $\mathrm{pHzpc}=5.8$ (in accordance with 438 previously published values ${ }^{4}$ ), since aggregation is commonly 439 favoured at $\mathrm{pH}$ close to the $\mathrm{pHzpc}$. Therefore, particles exhibiting 440 negative charges likely formed coarser aggregates when the $\mathrm{pH}$ 441 approached the pHzpc because of favorable electrostatic 442 interactions $^{64}$.

\begin{tabular}{|c|c|c|c|c|c|c|c|c|c|c|c|c|}
\cline { 2 - 15 } \multicolumn{1}{c|}{} & \multicolumn{2}{c|}{ Magnetite } & \multicolumn{2}{c|}{ HA-Magnetite } & \multicolumn{3}{c|}{ PC-Magnetite } & \multicolumn{3}{c|}{ Maghemite } & \multicolumn{2}{c|}{ Hematite } \\
\hline $\mathrm{pH}$ & 6 & 5 & 4 & 3 & 7.5 & 5 & 4 & 7.5 & 6 & 5 & 7.5 & 5 \\
\hline Range $(\mu \mathrm{m})$ & $\begin{array}{c}0.04-0.4 ; \\
1.6-32\end{array}$ & $\begin{array}{c}0.04-0.4 ; \\
1.6-32\end{array}$ & $0.04-18$ & $\begin{array}{c}0.04-0.4 ; \\
1.1-19\end{array}$ & $\begin{array}{c}0.04-0.4 ; \\
1.2-45\end{array}$ & $\begin{array}{c}0.04-0.4 ; \\
1.1-40\end{array}$ & $\begin{array}{c}0.04-0.4 ; \\
1.6-56\end{array}$ & $\begin{array}{c}0.04-0.4 ; \\
1.6-28\end{array}$ & $\begin{array}{c}0.04-0.4 ; \\
1.6-28\end{array}$ & $\begin{array}{c}0.5-0.7 ; \\
1.1-28\end{array}$ & $0.04-6$ & $\begin{array}{c}0.04-0.4 ; \\
1.1-12\end{array}$ \\
\hline Mode $(\mu \mathrm{m})$ & 0.04 & 0.04 & 0.04 & 0.04 & 0.04 & 0.04 & 0.04 & 0.04 & 0.04 & 8 & 1.4 & 0.04 \\
\hline Mean $(\mu \mathrm{m})$ & 1.3 & 0.9 & 0.4 & 0.6 & 1.1 & 0.8 & 1.3 & 4.1 & 1.1 & 6.8 & 1.3 & 0.5 \\
\hline Median $(\mu \mathrm{m})$ & 0.07 & 0.04 & 0.04 & 0.07 & 0.07 & 0.04 & 0.07 & 0.2 & 0.04 & 7 & 1.2 & 0.04 \\
\hline PDI & 1.38 & 2.74 & 13 & 5 & 1.9 & 3.4 & 1.3 & 0.56 & 2.06 & 0.72 & 4.8 & 7.6 \\
\hline
\end{tabular}

Table 2: Size distribution characteristics of each NP at some typical pH (aggregation state versus colloidal stability). The table shows the size-range, mode, mean size, median value and the PDI (polydispersity index) of magnetite, HA-coated magnetite, PC-coated magnetite, maghemite and hematite. High PDI have values up to 1.0 and very high PDI are up to 2.0. 
459

460

461

462

463

464

465

466

467

468

469

470

471

472

473

474

475

476

477

478

479

480

481

482 483

513
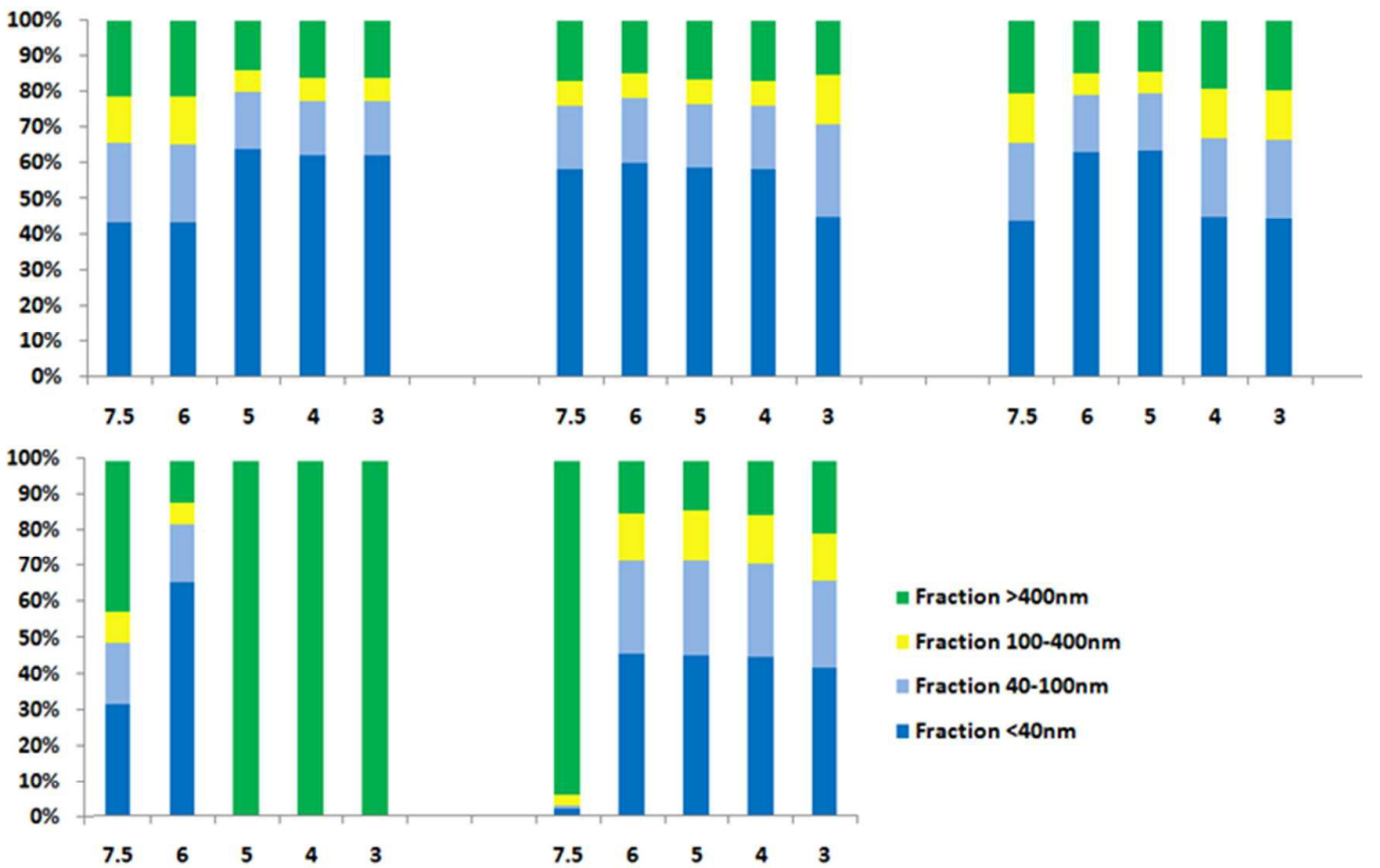

Fig 4: Evolution of four typical size-class (proportion in \%) with $\mathrm{pH}$ for a) magnetite, b) HA-magnetite, c) PC-magnetite, d) maghemite and e) hematite. Below the histograms, the table displaved the percentages of each fraction for typical $\mathrm{pH}(3,4,5,6$ and 7.5$)$.

485 HA-Magnetite. HA-magnetite nanoparticles displayed both a 539 Maghemite. The size distribution displayed three configurations as 486 continuous size distribution $(\mathrm{pH}=4$ to $\mathrm{pH}=7.5)$ and a dual size 540 distinct fractions whose proportions were strongly controlled by the 487 distribution $(\mathrm{pH}=3$ ). In both cases, fraction below $0.04 \mu \mathrm{m}$ was $541 \mathrm{pH}$. At a weak basic $\mathrm{pH}(\mathrm{pH}=7.5)$, the distribution was highly 488 more important but their proportion decreased as the $\mathrm{pH}_{542}$ polydispersed and made up of coarse aggregates (>0.4 $\mu \mathrm{m}$ ), which 489 decreased from $\mathrm{pH}=4$ to 3 . This decrease was accompanied by a 543 spread over a large size range. Maghemite NP displayed colloidal 490 slight increase in 40-100 nm-sized fraction and an increase in the 544 stability at $\mathrm{pH}=6$ with a size distribution similar to that of 491 proportion of coarser intermediate 100-400 nm NP size-class, which 545 magnetite. However, when the $\mathrm{pH}$ decreased to a more acidic $\mathrm{pH}$ 492 appeared to be more dependent upon $\mathrm{pH}$ than other fractions. The $546(\mathrm{pH}=5,4$ and 3$)$, small-sized NP and NP aggregates disappeared to 493 occurrence rate of the coarse aggregate fraction $(>0.4 \mu \mathrm{m}$ and $>1.1547$ form much coarser aggregates with almost exclusively $\mu \mathrm{m}$-scale $494 \mu \mathrm{m}$ ) remained constant regardless of the $\mathrm{pH}$, hence a lower $\mathrm{pH} 548$ sizes (>1 $\mu \mathrm{m})$. Thus, the maghemite size distribution would be in 495 implied a moderated aggregation with small $(\leq 0.04 \mu \mathrm{m})$ particles 549 good agreement with a high pHzpc close to $7.5^{67,68}$, as it became 496 aggregating in only slightly coarser (0.05-0.4 $\mu \mathrm{m})$ aggregates. Thus 550 coarser than at $\mathrm{pH}=6, \mathrm{but}$ the high aggregation observed from $\mathrm{pH}$ 497 in HA-coated iron oxide NP, HA appeared to be an effective organic $551=3$ to 5 suggested the possible implication of parameters other 498 stabilizer towards iron oxide NP as previously demonstrated ${ }^{65,66}$. 552 than electrostatic interactions to drive maghemite colloidal 499 PC-Magnetite. PC-magnetite nanoparticles highlighted two size 553 stability.

500 distribution depending on the $\mathrm{pH}$. At $\mathrm{pH}=6$ and 5, the size 554 Hematite. The hematite size distribution showed two $\mathrm{pH}$ 501 distribution was similar to that of bare magnetite at acidic $\mathrm{pH}(\mathrm{pH}=555$ dependent size distribution patterns. At $\mathrm{pH}=7.5$, the sizes were 5023 and $\mathrm{pH}=4$ ) where the colloidal stability displayed its maximum. 556 continuously distributed with a unique narrow size range composed $503 \mathrm{At} \mathrm{pH}=7.5,4$ and 3, $\mathrm{Fe}_{3} \mathrm{O}_{4}-\mathrm{PC}$ showed a similar size distribution to 557 of coarse homogeneous sizes displaying high polydispersity 504 bare magnetite at $\mathrm{pH}>6$, when it aggregated. When the $\mathrm{pH} 558$ (multimodal distribution centered on $1.4 \mu \mathrm{m}$ ). When the $\mathrm{pH}$ 505 decreased to $\mathrm{pH}=4$ and $\mathrm{pH}=3$, small aggregates $(\leq 0.04 \mu \mathrm{m})$ were 559 decreased to $\mathrm{pH}=6$ and lower, the $\mathrm{pH}$ drastically modified the 506 still the most common but in a lower proportion which was 560 hematite size distribution to a more stable aggregation state 69 507 compensated by a higher amount of the three other coarser size 561 characterized by a monomodal distribution ( $0.04 \mu \mathrm{m}$ ) and higher 508 fractions (in order: $40-100 \mathrm{~nm} ;>1.6 \mu \mathrm{m}$ and 100-400 nm). Although 562 abundance of finer particles (<0.4 $\mu \mathrm{m}$ ). In accordance with the 509 100-400nm-sized aggregates were still the least common, this 563 hematite $\mathrm{pHzpc}$ at $\mathrm{pH}=8.2$, hematite $\mathrm{NP}$ tended to aggregate when 510 fraction was the most sensitive to $\mathrm{pH}$ as its proportion more than 564 the $\mathrm{pH}$ reached $\mathrm{pH}=7.5$. 511 doubled from $\mathrm{pH} 6$ and 5 to $\mathrm{pH} 4$ and 3. 512
565 Effects of coating. The physico-chemical characteristics 566 obtained from the combination of HR-TEM and ATR-FTIR showed 
567that HA have been successfully coated onto magnetite NP.621 displaying coarse aggregates with homogeneous sizes suggests that 568 According to HR-TEM images, HA coating on magnetite did not 622 other mechanisms are involved at basic pH. Further investigations 569 affect the original morphology and size of the precursor NP. As the 623 are thus needed to fully assess iron oxide NP colloidal stability ${ }^{74-76}$. 570 surface modification with HA provided primarily acidic functional 624 Environmental perspectives. Aggregation and stabilization have 571 groups, the HA-coated magnetite pHzpc likely decreased to a lower 625 significant effects on the mobility, reactivity and environmental fate $572 \mathrm{pH}$ ( $\mathrm{pHzpc}=2.3$ ). Accordingly, magnetite-HA promoted colloidal 626 of NP. Once released in surface waters, unstable particles tend to 573 stability from $\mathrm{pH}=7.5$ to $\mathrm{pH}=4$ because of repulsive electrostatic 627 agglomerate, sediment or flocculate or they preferentially adsorb 574 interactions. The aggregation observed at $\mathrm{pH}=3$ - close to the new 628 onto bigger particles or surfaces ${ }^{77}$. As a result, aggregated NP that $575 \mathrm{pHzpc}$ - would then be explained by the lack of negative surface 629 form larger colloids with a possible smaller surface area are less 576 sites to compensate for the protonation induced by the $\mathrm{H}^{+} 630$ easy to transport and do not get through the soil as easily as smaller 577 concentration increase in the aqueous solution. Both HA and bare 631 particles ${ }^{78}$. As aggregated NP become less mobile, they may 578 magnetite evidenced that the proportion of their size- fractions was 632 become more ineffective in acting as nutrient carriers ${ }^{79}$. It is also 579 strongly controlled by the $\mathrm{pH}$, which induced either colloidal 633 more difficult for these colloids to be taken up by plants and living 580 stability or aggregation. Nevertheless, HA coating promoted 634 organisms as they are less soluble than their smaller counterparts ${ }^{80}$. 581 smaller-sized aggregates as well as a narrower size distribution and 635 The dissolution of NP induces the mobilization of ions which are 582 more homogeneous stable sizes (especially for coarser particles636likely complexed with molecules that foster their absorption by $583(>0.4 \mu \mathrm{m})$ ) compared to bare magnetite (Table 2). This enhanced 637 plants and animals. In addition, depending on their concentration 584 stabilization may stem from a HA steric barrier that helped maintain 638 and speciation as well as on the physiology of the organism that 585 a space between the particles to prevent the aggregation of $\mathrm{NP}^{70,71} .639$ absorbs it, metal atoms or ions can be either positive nutrients or ${ }_{586}$ Similar to the HA coating, the PC surface modification did not affect 640 toxic elements. On the other hand, aggregation may directly affect 587 the size and morphology of magnetite. Magnetite coated with $\mathrm{PC}_{641}$ NP toxicity towards living organisms since smaller NP have been 588 displayed a different colloidal behaviour as compared to bare 642 shown to penetrate the cell walls of certain species more easily ${ }^{81,82}$. 589 magnetite. As PC imparted both negative and positive surface 643 Considering the $\mathrm{pH}$ effect, the physicochemical properties of the 590 groups on the surfaces of the NP (glycerophosphate group, 644 soil solution have to be considered in order to accurately assess the 591 trimethylethanolammonium group), and because of the complex 645 fate of NP in the environment. NP intrinsic properties, such as their 592 and heterogeneous surface structures that are generated by 646 surface chemistry, are also of prime importance since they are 593 adsorbed $\mathrm{PC}^{72}, \mathrm{PC}$-coated nanoparticles likely displayed variable 647 involved in both electrostatic and steric interactions, which may 594 colloidal behaviours. As compared to magnetite, PC-NP showed 648 impact their dispersion, bioavailability and biocompatibility ${ }^{83}$.In 595 similar size proportions and repartition although the magnetite-PC 649 natural waters and surficial aerobic environments, NP likely 596 coarse fraction displayed a few large aggregates (hence its wider650 undergo many surficial modifications and become embedded in 597 size range, see Table 2) regardless of the $\mathrm{pH}$. PC-NP were thus 651 matrixes or functionalized with specific molecules ${ }^{84}$. As a result, 598 probably able to form highly contrasted structures (according to 652 these attached molecules can both passivate and/or confer their 599 their size) suggesting that PC-coated magnetite did not entirely653own properties to mineral surfaces; e.g. polyanionic HA coating on 600 depend on electrostatic interactions but also on steric forces ${ }^{72}$. 654 magnetite, resulting in a lower pHzpc and enhanced colloidal 601 Effects of iron oxide intrinsic physicochemical properties. The 655 stability. In addition, HA coating - as well as PC covering - might 602 oxidation of magnetite $\left(\mathrm{Fe}_{3} \mathrm{O}_{4}\right)$ to maghemite $\left(\gamma-\mathrm{Fe}_{2} \mathrm{O}_{3}\right)$ did not 656 passivate iron oxide NP surfaces to yield a steric barrier that 603 change morphology and particle size. Maghemite still displayed a 657 prevents Fe leakage from mineral surfaces and the ageing of the 604 higher surface area $\left(131 \mathrm{~m}^{2} \mathrm{~g}^{-1}\right)$ than magnetite $\left(115 \mathrm{~m}^{2} \mathrm{~g}^{-1}\right)$ and 658 magnetic core by oxidation. HA, which are ubiquitous in most 605 oxidized NP very likely yielded intrinsic compositional differences. 659 aquatic systems, display a specific affinity for iron oxide NP as well 606 These modifications probably resulted in a higher surface potential 660 as trace elements and therefore HA-iron oxide NP complexed 607 thereby explaining the variable size distributions observed as the 661 structures may also enhance ETM adsorption to NP. However, $608 \mathrm{pH}$ changed. Maghemite NP aggregation was favoured at acidic $\mathrm{pH}_{662}$ although natural coatings demonstrated improved iron oxide NP 609 (equal or below 5), which would be in good agreement with their 663 stability and reactivity, their effects depend upon the amount and 610 high surface potential. Indeed, the tendency to form large 664 chemical composition of the substances ${ }^{4}$.

611 aggregates at these $\mathrm{pH}$ values likely resulted from a high energetic 665 The rapid oxidation of magnetite into maghemite is important since 612 barrier that had to be overcome at the mineral surfaces ${ }^{73}$. Indeed, 666 iron plays an active redox catalytic role in many energy transfer and 613 increasing NP surface to volume ratio leads to a higher surface 667 electron transfer processes ${ }^{85-87}$. The iron oxide redox state also 614 energy which induces aggregation between particles. As hematite 668 plays a key role in specific anaerobic environments where Fe(II) and 615 displayed a much lower surface area, the higher colloidal stability $669 \mathrm{Fe}(\mathrm{III})$ are used as energetic catalysts for bacteria ${ }^{88,89}$. Finally, the 616 observed over a wide $\mathrm{pH}$ range may result from a lower energetic 670transformation of magnetite into maghemite is also relevant 617 barrier at the surface of the particles in accordance with NP having 671 considering its adsorption capacity towards environmental 618 a relatively lower surface potential. Hematite stability would thus 672 compounds ${ }^{90}$. Several questions are raised from these 619 be related, in part, to its smaller surface area and surface potential. 673 environmental considerations, especially, what are the impacts of 620 However, the typical aggregation behaviour of hematite NP674these modifications regarding iron oxide NP reactivity? 


\section{${ }_{675}$ Conclusions}

676 The $\mathrm{pH}$ appears to be a key driver in controlling iron oxide $\mathrm{NP}^{725}$ 677 colloidal behaviour as resulting from protonation and ${ }^{726} 7$ 678 deprotonation reactions of surface hydroxyl-groups. Surface ${ }^{727}$ 679 modifications also implied considerable effects on iron oxide NP ${ }^{7288}$ 680 colloidal stability as they promoted electrostatic interactions. In $^{7299}$ 681 contrast to PC, HA was shown to be particularly efficient in ${ }^{730}$ 682 enhancing magnetite colloidal stability. Magnetite seems to be ${ }^{731}$ 683 highly unstable in aerobic conditions. The oxidation of magnetite ${ }^{73210}$ 684 into maghemite modified its surface chemistry and surface area, ${ }^{733}$ 685 and these modifications resulted in higher aggregation at most $\mathrm{pH}^{73411}$ 686 values. Compared to maghemite, hematite appeared to be less ${ }^{735}$ 687 sensitive to $\mathrm{pH}$ and displayed a lower surface area and surface ${ }^{73612}$ 688 potential. Both hematite and maghemite displayed high ${ }^{737}$ 689 aggregation size distributions at different $\mathrm{pH}$ values.

${ }_{690}$ Considering the widespread use of iron oxide NP and their ${ }^{739}$ 691 subsequent release in the environment, their fate and behaviour in ${ }^{74014}$ 692 soils and natural waters raise many environmental questions not ${ }^{741}$ 693 only in terms of their possible impacts on living organisms but also ${ }^{742} 15$ 694 for their mobility and fate in ecosystems. Therefore, more attention ${ }^{743}$ 695 should be paid for the understanding of colloidal and chemical ${ }^{74416}$ 696 stabilities of iron oxide NP as it is likely involved in many major ${ }^{745}$ 697 interactions within the environment.

\section{${ }_{698}$ Acknowledgements}

${ }_{69}$ We are thankful to François Pustoc'h for the time as well as the ${ }^{750}$ 700 thorough advices he gave us to conduct laser particle analyses at ${ }^{751} 19$ 701 the CReAAH (University of Rennes1). Dr Patricia Benard-Rocherullé 702 and Dr Vincent Dorcet (ISCR, University of Rennes1) are deeply 75320 703 acknowledged for DRX and MET studies, respectively. Dr Fabienne 704 Gauffre is thanked for her kind help to perform NTA measurements. 705 Last, Dr S. Mullin is acknowledged for post-editing the English style ${ }^{75621}$ 706 (http://www.proz.com/profile/677614). This study was funded by ${ }_{758}^{757}$ 707 both the CNRS-INSU/INEE EC2CO and the Interdisciplinarity Mission ${ }^{758}$ 708 programs through 'NanoOrgaTraces' and 'ALIEN' projects, 709 respectively both awarded to Mathieu Pédrot and the University ${ }_{761}^{760}$ 710 Rennes 1 through 'Défis Scientifiques Emergents' program awarded 711 to Aline Dia.

\section{${ }_{712}$ References}

714 http://trove.nla.gov.au/version/36973177, 2003, Edited by 76826 715 Wiley-VCH, 664p.

7162 M. F. Hochella Jr, S. K. Lower, P. A. Maurice, R. L. Penn, N. 77027 717 Sahai, D. L. Sparks and B. S. Twining, Science, 2008, 139, 771 $718 \quad 1631$.

7193 A. Afkhami, M. Saber-Tehrani and H. Bagheri, Desalination, 773 $720 \quad$ 2010, 263, 240.

7214 M. A. Ahmed, S. M. Ali, S. I. El-Dek and A. Galal, Materials 775 722 Science and Engineering B, 2013,178, 744.
S. Laurent, J.-L.Bridot, L. Van der Elst and R. N. Muller, Future Medicinal Chemistry, 2010, 2(3), 427.

H. Guo and A. Barnard, Journal of Materials Chemistry A, 2013, 1, 27.

M. Schindler and M. F. Hochella Jr., Geology, 2016, 44, 515.

S. C. Löhr, D. T. Murphy, L. D. Nothdurft, R. Bohlar, S. Piazolo and C. Siegel, Geochimica and Cosmochimica Acta, 2017, 200, 25.

C. W. Isaacson, M. Kleber and J. A. Field, Environmental Science \& Technology, 2009, 43,6463.

B. Nowack and T.D. Bucheli, Environmental Pollution, 2007, $150,5$.

M. Auffan, J. Rose, J.-Y.Bottero, G. V. Lowry, J.-P.Jolivet and M.-R.Wiesner, Nature Nanotechnology, 2009, 4, 634.

G. V. Lowry, K. B. Gregory, S. C. Apte and J. R. Lead, Environmental Science \& Technology, 2012, 46, 6893.

S. C. N. Tang, I. and M. C. Lo, Water Research, 2013, 47, 2613.

M. Vitkova, S. Rakosova, Z. Michalkova, M. Komarek, Journal of Environmental Management, 2017, 186, 268.

P. N. Dave and L. V. Chopda, Journal of Nanotechnology, 2014, 2014, 1.

A. Aftabtalab, H. Sadabadi, CH. Shilpa Chakra, K. V. Rao, S. Shaker and E. Privilege Mahofa, International Journal of Scientific \& Engineering Research, 2014, 5(1),1419.

S. R. Chowdhury and E. K. Yanful, Journal of Environmental Management, 2013, 129, 642.

L. R. Khot, S. Sankaran, J. M. Maja, R. Ehsani and E. W. Schuster, Crop Protection, 2012, 35, 64.

E. Navarro, A. Baun, R. Behra, N. B. Hartmann, J. Filser, AJ.Miao, A. Quigg, P. H. Santschi and L. Sigg, Ecotoxicology, 2008,17, 372.

A. Valdiglesias, N. Fernandez-Bertolez, G. Kiliç, C. Costa, S. Costa, S. Fraga, M. J. Bessa, E. Pasaro, J. P. Texeira and B. Laffon, Journal of Trace Elements in Medicine and Biology, 2016, 38, 53.

R. Podila and J. M. Brown, Journal of Biochemical and Molecular Toxicology, 2013, 27(1), 50.

W. Wu, Z. Wu, T. Yu, C. Jiang and Woo-Sik Kim, Sci. Technol. Adv. Mater., 2015, 16, 023501.

O. Veiseh, J. W. Gunn, M. Zhang, Advanced Drug Delivery Review, 2010, 62, 304.

Y. Ju-Nam and J. R. Lead, Science of the Total Environment, 2008, 400, 414.

A-H. Lu, E.L. Salabas and F. Schüt, Angew. Chem. Int. Ed., 2007, 46, 1244.

D. Maity and D.C. Agrawal, Journal of Magnetism and Magnetic Materials, 2007, 308, 46.

M. M. Can, M. Coskun and T. Firat, Journal of Alloys and Compounds, 2012, 542, 241.

A. Lassoued, M. S. Lassoued, B. Dkhil, A. Gadri and S. Ammar, Journal of Molecular Structure, 2017, 1141, 99 S. C. Pang, S. F. Chin and M. A. Anderson, Journal of Colloid and Interface Science, 2007, 311, 94. 
77831 L. Peng, P. Qin, M. Lei, Q. Zeng, H. Song, J. Yang, J. Shao, B. 833 779 L. and J. Gu, Journal of Hazardous Materials, 2012,209-834 $780 \quad 210,193$. 78132 E. Tombacz, Z. Libor, E. Illès, A. Majzik and E. Klumpp, ${ }^{83654}$ $782 \quad$ Organic Geochemistry, 2004, 35, 257.

78333 A. M. Vindedahl, J. H. Strehlau, W. A. Arnold and R. L. Penn, ${ }^{83855}$ 784 Environmental Science: Nano, Critical Review, 2016, 3, 1. 78534 M. Baalousha, The Science of the Total Environment, 2009, ${ }^{840} 56$ $786 \quad 407,2093$.

78735 E. Illes and E. Tombacz, Journal of Colloid and Interface ${ }^{84257}$ 788 78936

Science, 2006, 295,115.

E. Tombacz, I.Y. Toth, D. Nesztor, E. Illés, A. Hadju, M. ${ }^{84458}$ Szekeres and L. Vékas, Colloids and Surfaces $A:^{845}$ A. Hajdú, E. Illés, E. Tombácz and I. Borbáth, Colloids and ${ }^{847}$ surfaces A: Physicochemical and Engineering Aspects, 2009, ${ }^{848} 60$ 347, 104.

J. Hao, C. Cleveland, E. Lim, D. R. Strongin and M. A. A. ${ }^{85061}$ Schoonen, Geochemical Transactions, 2006, 7:8, 1. Schoonen and S. T. Martin, Environmental Science $\&_{85463}^{853}$ Technology, 2006, 40, 1511 J. Giri, S. G. Thakurta, J. Bellare, A. K. Nigam and D. Bahadur, ${ }_{856}^{855} 64$ Journal of Magnetism and Magnetic Materials, 2005, 293, 857 62. 858

S. Chatterjee, M. Krikorian, H. D. Gafney and B. Gersten, 85965 Material Research Society, 2011, 1061, MM09-08. 860 R. Frison, G. Cernuto, A. Cervellino, O. Zaaharko, G. M. 86166 Colonna, A. Guagliardi and N. Masciocchi, Chemistry of 862 Materials, 2013, 25, 4820. 86367 U. S. Khan, Amanullah, A. Manan, N. Khan, A. Mahmood and 864 A. Rahim, Material Science-Poland, 2015, 33(2), 278. I. Nedkov, T. Merodiiska, L. Slavov, R.E. Vandenberghe, Y. 86669 Kusano and J. Takada, Journal of Magnetic Materials, 2006, 867 300, 358. $\mathrm{H}$. Shokrollahi, Journal of Magnetism and Magnetic 869 Materials, 2017, 426, 74. 87071 L. Charlet G. Morin, J. Rose, Y. Wang, M. Auffan, A. Burnol 871 and A. Fernandez-Martinez, ComptesRendus Geoscience, 872 2011, 343, 123.

L. Chekli, S. Phuntsho, M. Roy, E. Lombi. E. Donner and H. K. 874 Shon, Water Research, 2013, 47, 4585. W. Li, J. Wu, C. Kim and J. D. Fortner, Environmental Science 876 \&Technology, 2014, 48(20), 11892. A. Navrotsky, L. Mazeina and J. Majzlan, Science, 2008, 319, 878 1635. R. Massart, IEEE Transactions on Magnetics, 1981, 17,1247. 880 S. E. Khalafalla and G. W. Reimers, IEEE Transactions on 88176 Magnetics, 1980, 16(2), 178.

882 Z. B. Anna, B. Patricyja, J. Petr, E. Petrovsky, B. Pavel, H. 88377 Daniel, Colloids and Surfaces B: Biointerfaces, 2016, 141,884 389. Physicochemical and Engineering Aspects, 2013,435, $91 . \quad 84659$

X. V. Zhang, T. A. Kendall, J. Hao, D. R. Strongin, M. A. A. ${ }^{85262}$
Chmeleff, C. Cloquet, S. Delpoux, M. Labatut, R. Losno, C. Pradoux Y. Sivry and J. E. Sonke, Geostandards and Geoanalytical Research, 2013, 37(4), 449.

C. A. Gorski and M. M. Sherer, American Mineralogist, 2010, 95, 1017.

P. Komadel and J. W. Stucki, Clays and Clay Minerals, 1988, 36(4), 379.

W. Cheng, R. Marsac and K. Hanna, Environ. Sci. Technol., 2018, 52 (2), 473.

J. Lohdia, G. Mandarano, N. J. Ferris, P. Eu and S. F. Cowell, Biomedical Imaging and Intervention Journal, 2010,6(2), 1. H. Niu, D. Zhang, S. Zhang, X. Zhang, Z. Meng and Y. Cai, Journal of Hazardous Materials, 2011, 190, 559.

J.-F. Liu, Z.-S. Zhao and G.-B.Jiang, Environmental Science \& Technology, 2008, 42, 6949.

S. Koesnarpadi, S. J. Santosa, D. Siswanta and B. Rusdiarso, Procedia Environmental Sciences 30 (2015, 103.

S. Debnath, D. B. Hausner, D. R. Strongin and J. Kubicki, Journal of Colloids and Interface Sciences, 2010, 341, 215.

Q.-C. Le, M.-H. Ropers, H. Terrisse and B. Humbert, Colloids and Surfaces B: Biointerfaces, 2014, 123, 150.

J. Buffle, K. Wilkinson, S. Stoll, F. Montserrat, Z. Jingwu, Environmental Science \& Technology, 1998, 32(19), 2899.

A. Kraynov and T. E. Müller, In Applications of Ionic Liquids in Science and Technology, 2011, Edited by Prof. S. Handy (516 pages), 235.

M. Pédrot, A.L. Boudec, M. Davranche, A. Dia, O. Henin, Journal of Colloid and Interface Science, 2011, 359, 75.

D. Palomino and S. Stoll, Journal of Nanoparticle Research, 2013, 15(2), 1428.

N. Fauconnier, J. N. Pons, J. Roger and A. Bee, Journal of Colloid and Interface Science, 1997,194, 427.

L. Vayssieres, J. Phys. Chem. C, 2009, 113, 4736.

K. Shimizu, S. V. Sokolov and R. G. Compton, Colloid and Interface Science Communications, 2016, 13, 19.

S. Ghosh, W. Jiang, J. D. McClements and B. Xing, Langmuir, 2011, 27, 8036.

S. F. Meideros, J. O.C. Filizzola, V. F.M. Fonseca, P. F.M. Oliveira, T. M. Silva, A. Elaissari and A. M. Santos, Materials Letters, 2015, 160, 522.

R. Michel and M. Gradzielski, International Journal of Molecular Sciences, 2012, 13, 11610.

K. A. D. Guzman, M. P. Finnegan and J. F. Banfield, Environmental Science \& Technology, 2006, 40, 7688.

M. D. Carvalho, F. Henriques, L. P. Ferreira, M. Godinho and M. M. Cruz, Journal of Solid State Chemistry, 2013,201, 144.

E. Alp and N. Aydogan, Colloids and Surfaces A: Physicochemical and Engineering Aspects, 2016, 510, 205.

D. Dickson, G. Liu, C. Li, G. Tachiev and Y. Kai, The Science of the Total Environment, 2012, 429, 170.

A. M. Badawy, A. A. Hassan, K. G. Scheckel, M. T. Suidan and T. M. Tolymat, Environmental Science and Technology, 2013, 47, 4039.

M. Komarek, A. Vanek and V. Ettler, Environmental Pollution, 2013, 172, 9. 
88879 C. Claudio, E. di lorio, Q. Liu, Z. Jiang, V. Barron, Journal of

889 Nanoscience and Nanotechnology, 2017, 17(7), 4449.

89080 I. A. Mudunkotuwa and V. H. Grassian, Journal of $891 \quad$ Environmental Monitoring, 2011, 13(5), 1135.

89281 J. Bauman, J. Köser, D. Arndt and J. Filser, The Science of the 893 Total Environment, 2014, 484, 176.

89482 K. Powers, M. Palazuelos, B. M. Moudgil and S. M. Roberts, $895 \quad$ Nanotoxicology, 2007,1 (1), 42.

89683 R. K. Das, S. K. Brar and M. Verma, Trends in Biotechnology, $897 \quad 2016,34(6), 440$.

89884 D. Lin, S. D. Story, S. L. Walker, Q. Huang, W. Liang and P. 899 Cai, Environmental Pollution, 2017, 228, 35.

90085 K. S. Siddiqi, A. ur Rahman, Tajuddin and A. Husen, $901 \quad$ Nanoscale Research Letters, 2016, 11, 498.

90286 H. Wu, J. J. Yin, W. G. Wamer, M. Zeng and Y. M. Lo, Journal 903 of Food and Drugs Analysis, 2014, 22, 86.

90487 S. K. Chaudhuri, J. G. Lack, J. D. Coates, Applied and 905 Environmental Microbiology, 2001, 67, 2844.

90688 M. Posfai, T. Kasama, E. T. Simpson, R. K. K. Chong and R. E. 907 Dunin-Borkowski, ActaCrystallica, 2006, 62, 39.

90889 J.-Y. Bottero, M. Auffan, J. Rose, C. Mouneyrac, C. Botta, J. 909 Labille, A. Masion, A. Thill and C. Chaneac, ComptesRendus Geoscience, 2011, 343, 168.

91190 M. Davranche, A. Dia, M. Fakih, B. Nowack, G. Gruau, G. 912 Ona-Nguema, P. Petitjean, S. Martin and R. Hochreutener,

913 Chemical Geology, 2013,335, 24. 